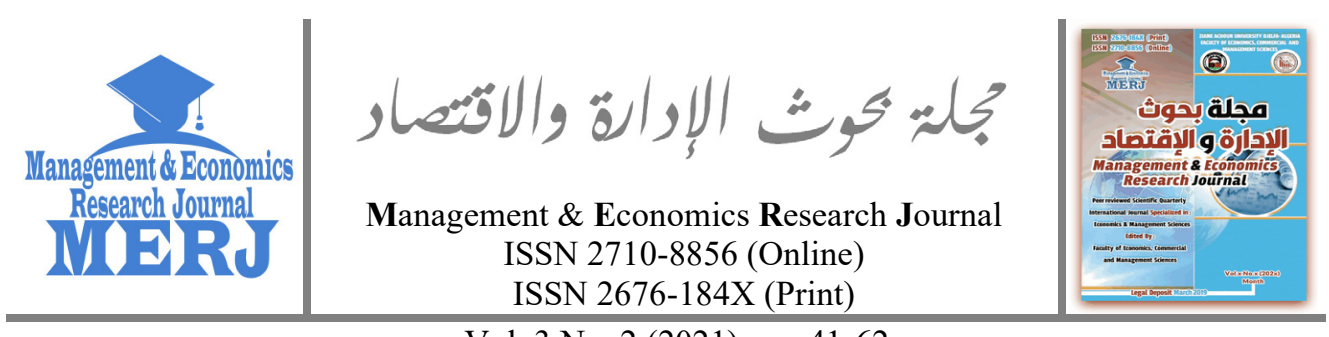

Vol. 3 No. 2 (2021), pp. 41-62

https://doi.org/10.48100/merj.2021.157

Check for updates

\title{
Workers' Remittances in Yemen: Macroeconomic Determinants and Impact on Economic Growth
}

\author{
Essa A. Alhannom ${ }^{1}$, Ghaleb S. Mushabeb ${ }^{2}$ \\ ${ }^{1}$ Associate Professor of Economics, Faculty of Administrative Sciences, \\ Ibb University (Yemen) \\ $\triangle$ eysa20@gmail.com \\ ${ }^{2}$ Associate Professor of Economics, Faculty of Administrative Sciences, \\ Ibb University (Yemen) \\ $\checkmark$ galrazhi@gmail.com
}

Received: 01-03-2021

Accepted: 11-04-2021

Published online: 12-04-2021

\section{How to Cite:}

Alhannom, E. A., \& Mushabeb , G. S. (2021). Workers' Remittances in Yemen: Macroeconomic Determinants and Impact on Economic Growth. Management \& Economics Research Journal, 3(2), 41-62. https://doi.org/10.48100/merj.2021.157

\section{Abstract:}

This study examines the determinants of workers' remittances and their impact on economic growth in Yemen. Autoregressive Distributed Lag (ARDL) bounds test to co-integration and error correction model (ECM) were applied to data covering the period from 1990 to 2014. According to the model of remittances determinants, workers' remittances in Yemen respond to the macroeconomic conditions of both the home and host countries. In the long run, migrant stock and income levels at the host countries positively and strongly influence the remittance level, with a feeble impact on domestic inflation rates. The effect of the home country's income seems positive but insignificant in explaining the behaviour of remittances level. The economic growth model suggests that, in the long

•Corresponding author: IbbUniversity, Ibb (Yemen).

[囚eysa20@gmail.com]

(C2021 the Author(s). This is an open-access article distributed under the terms of (CC BY-NC 4.0) which permits use, distribution and reproduction in any medium, provided the original work is properly cited and is not used for commercial purposes. 
run, the impact of workers' remittances appears to be positive and moderate, with positive and stronger influences observed for financial development and official development assistance. Accordingly, it is recommended that a lesser weight should be given to remittances in the strategic planning process, considering the increasing potential of the conditions in the neighbouring host countries to be changed. In addition, using remittances as a means of economic growth can be enhanced by encouraging migrants to direct their savings towards productive investment activities and via formal channels.

Keywords: Remittances, Economic Growth, Time Series Analysis.

JEL Codes: F24, O47, C22

\section{Introduction}

Migrants' remittances are an important source of international financial flows to the recipient countries for alleviating poverty through financing consumption, improving households' living standards, and promoting economic growth by filling domestic saving-investment gaps. Remittances are a key subject in labour-exporting countries' growth and development studies. According to the World Bank estimates (2020b), workers' remittances reached US\$ 463.6 billion in 2010 and increased to US\$ 579.9 billion and US\$ 613.5 billion in 2014 and 2017, respectively. This importance comes to be more evident if we refer to other forms of international financial flows such as official development assistance (ODA), which is estimated to be US\$ 128.6 billion, US\$ 161.5 billion, and US\$ 165 billion for 2010, 2014, and 2017 respectively (World Bank, 2020a).

Yemen is a low-income country with tough opportunities for achieving acceptable livelihood and other economic ambitions. Accordingly, the outflow of hundreds of thousands of Yemeni labourers is motivated by economic considerations (better work opportunities and wages). Most Yemeni migrants head to the neighbouring oil-exporting countries, particularly Saudi Arabia, a critical host country. According to the World Bank (2020b), migration and remittances data, Saudi and Emirates were the destinations of $84.12 \%$ and $73.2 \%$ of total Yemeni expatriate labourers in 2010 and 2017, respectively, and the USA was the third destination receiving about $5 \%$ in the same years respectively.

Recently, Yemen has depended on migrants' remittances as a major source of international financial flows and foreign exchanges. According to the size of remittances received in 2019, Yemen ranks first among the 29 low-income countries and twenty-fifth among the 135 low and middleincome countries (World Bank, 2020c). With official estimates of more than 
1.2 million Yemeni workers abroad, remittances increased from US\$ 1.53 billion in 2010 to US\$ 3.343 billion and US\$ 3.77 billion in 2014 and 2017, respectively (World Bank, 2020a). As a percentage of GDP, remittances constituted 13\%, on average, between 1990 and 2014, whereas foreign direct investment (FDA) and ODA inflows averaged $6.24 \%$ and $3.4 \%$, respectively, for the same period of time. Figure 1 shows the trends of remittances, FD, and ODA inflows during this period, where remittances appear to be bigger than FDI and ODA inflows in most years.

Additionally, taking into account that most of the FDI inflows during this period were provisional and the volatile nature of ODA inflows, remittances became the most crucial source of foreign finance. The jump in remittances in 2012 and beyond resulted from the improvement measures in the estimation and coverage of remittances data, which was implemented by the central bank of Yemen (United Nations Economic and Social Commission for West Asia [ESCWA], 2014, p.11). Therefore, workers' remittances in Yemen have been underestimated before 2012, and even after 2012, both remittances transferred through informal channels and remittances in the form of goods are still not included. Workers' remittances play another essential role in alleviating the current account's deficit of the balance of payments, as the trade, services, and investment income balances are in permanent deficits.

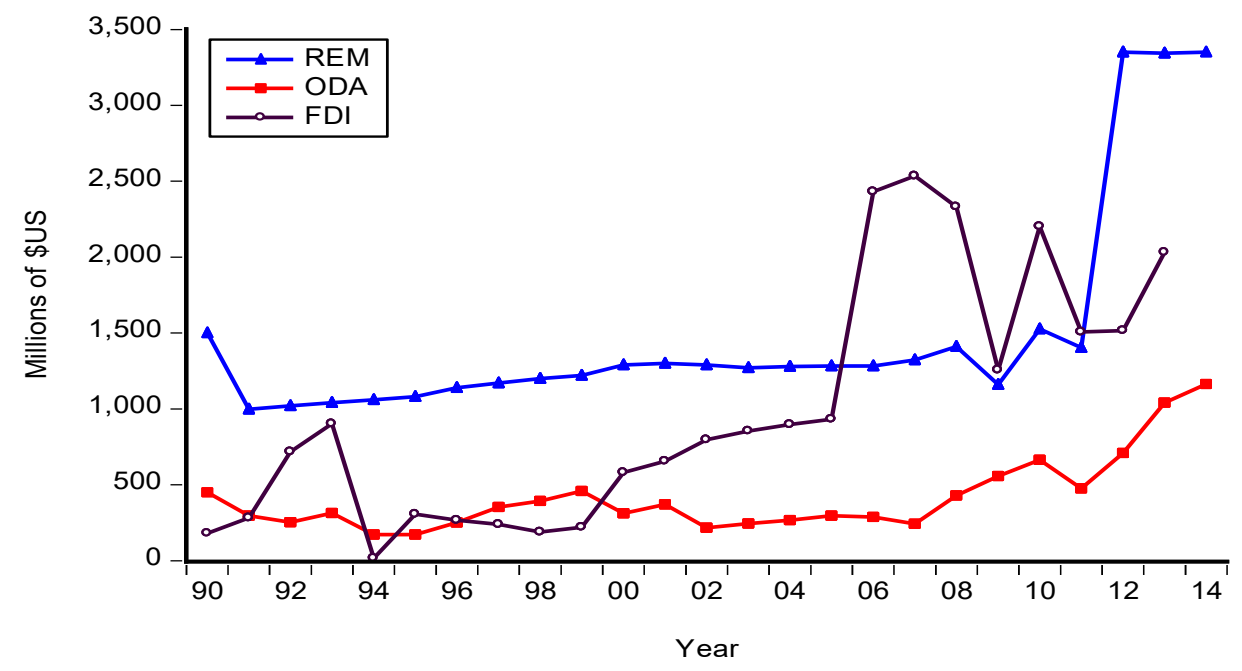

Figure 1. The trend of remittances, ODA, and FDI inflows in Yemen 1990-2014 Source: World Bank, WDI online data bank (2020a).

The growing size and socio-economic effects of workers' remittances 
in Yemen, and the controversial views in the literature about remittances' determinants and developmental effects, raise two key questions that constitute this study's problem. What are the important macroeconomic factors affecting remittances inflows to Yemen, and what is the nature of the remittances' impact on economic growth?

To our knowledge, no previous econometric study has examined the macroeconomic aspects of Yemeni migrants' remittances. The study of MIM and Ali (2012) inspects the effect of remittances on economic growth in 15 MENA countries, including Yemen, for the period 1980-2009, using panel data analysis techniques. According to OLS and fixed effect techniques, the workers' remittances effect appeared to be positive and insignificant. However, the System Generalized Method of Moment (SGMM) analysis provides evidence for a positive and significant, but relatively weak, impact. According to their analysis of the relationships between remittances and investment and consumption, this weak impact of workers' remittances is interpreted as a result of directing most remittances towards consumption.

The current study investigates the determinant factors behind workers' remittances and the impact of remittances on economic growth in Yemen, using annual time series data for the period 1990-2014. In achieving this goal, the ARDL bounds testing approach to co-integration of Pesaran and Shin (1996) and Pesaran, Shin, and Smith (2001) and ECM will be applied. The ARDL bounds test is an advanced technique and the most appropriate for the data of Yemen, as it is believed to be valid and appropriate for small-size samples and can be applied irrespective of the degree of integration of the independent variables (Narayan, 2004).

The rest of this study proceeds as follows: section two reviews theoretical and empirical literature dealing with workers' remittances determinants and their impact on economic growth. Section three's subjects are econometric methodology and data used, whereas section four presents the empirical analysis. Conclusions and policy implications are in section five.

\section{Literature review}

\subsection{Determinants of remittances}

The literature on workers' remittances determinants takes either microeconomic or macroeconomic approaches. Microeconomics works on factors affecting the decision of a migrant to remit and, thus, the size of his remittances. Depending on the socio-demographic characteristics of 
migrants and their families have been the focus of most literature. Under this line of literature, three motives for remitting to the home country are identified: altruistic, self-interest, and contractual reasons (see Lucas \& Stark, 1985; Glytsos, 1988; Agarwal \& Horowitz, 2002). However, the works of macroeconomic determinants of remittances, which are still developing, address the aggregate level of remittances and, therefore, the economic conditions of both the home and host countries. From the home country's perspective, the economic activity level, proxied by GDP or real per capita GDP, migrant stock, exchange rate variations, interest rates, domestic inflation rates, and financial development, is considered important driving macroeconomic forces of remittances.

Nevertheless, macroeconomic factors in the host countries include, but are not limited to, economic activity level, unemployment rates, wages level, interest rates, and exchange rates. A higher level of economic activity in the host country means a higher demand for the migrant labour force and higher earnings, thus increasing remittances and vice-versa. This tendency is confirmed by many studies such as those of Elbadawi and Rocha (1992), Aydas, Neyapti, and Metin-Ozcan (2005), Silva and Huang (2006), Adenutsi (2014), and McCracken, Carlyn, and Stack (2017).

In the labour-exporting country, it is believed that an improvement in economic activity level will be reflected in a higher income and living standards of households. Thus, the needed money to be remitted is likely to decrease and vice-versa (Swamy, 1981). This refers to the counter-cyclical characteristic of remittances concerning the GDP of the home country, which is evidenced by El-Sakka and McNabb (1999), Yang and Choi (2007), Singh, Haacker, Lee, and Goff (2011), Moussir and Tabit (2016), and Hor and Pheang (2017). On the other hand, better economic activity in the country of origin increases the returns on real and financial investment. It will likely result in more remittances, which points to the pro-cyclical nature of remittances concerning the GDP of the home country. Higgins, Hysenbegasi, and Pozo (2004), Aydaş et al. (2005), Gupta (2005), Freund and Spatafora (2008), Adenutsi (2014), McCracken et al. (2017), and Yoshino, Farhad, Taghizadeh-Hesary, and Miyu (2019) observe a positive and significant effect of home country's GDP on the level of remittances inflows.

The stock of migrants abroad is another factor recognized in the literature as a determinant of the level of remittances. It is expected that the more the migrant stock of a country abroad, the higher the level of inward remittances will be. The works of Lianos (1997), Lueth and Ruiz-Arranz (2006), Freund and Spatafora (2008), Singh et al. (2011), Bettin, Presbitero, 
and Spatafora (2014), and Moussir and Tabit (2016), found evidence on this positive association between migrant stock and remittances level.

Domestic inflation in the labour-exporting country can affect the volume of remittances in both directions. The increase in domestic inflation rates lowers the real income; thus, maintaining purchasing power and consumption levels of households in the home country entails remittances to rise. Lianos (1997), Elsakka and Mcnabb (1999), Lueth and Ruiz-Arranz (2007), Begum and Sutradhar (2012), Adenutsi (2014), and Prasad and Trivedi (2015) show that remittances vary positively with inflation rates at the country of origin. By contrast, an increase in domestic inflation can be seen as an indicator of economic and political instability and hence suggests a decrease in remittances (see, for example, Katseli and Glytsos, 1986; Elbadawi \& Rocha, 1992; Aydas et al., 2005; Ezeoha, 2013). This literature review of remittance determinants reveals that the evidence is still far from conclusive, highlighting the need for more examination.

\subsection{Impact of remittances on economic growth}

Despite a large amount of literature regarding the impact of remittances inflows on the economic growth of the recipient countries, it is still surrounded by ambiguity. It has no definite answer (Barajas, Chami, Fullenkamp, Gapen, \& Montiel, 2009). Theoretically, remittances alleviate poverty by increasing households' income and living standards (see Ratha, 2013; Daway-Ducanes, 2015). They can positively, negatively, or neutrally influence economic growth depending on their use and the available channels. Remittances may enhance growth if they are invested in human capital development via financing the education and training activities (see Edwards and Ureta,2003), and the accumulation of physical capital (see Glytos, 2002; Lucas, 2005), and enabling households and entrepreneurs to overcome credit constraints (Mesnard, 2001). Other literature adds evidence on several indirect positive effects of remittances on economic growth, such as their resultant financial development (see Giuliano \& Ruiz-Arranz, 2009) and the reduction of output volatility (see Kroft \& Lloyd-Ellis, 2002; Fajnzylber \& Lo'pez, 2008; Chami, Hakura, and Montiel, 2009). The neutral or weak influence of remittances on economic growth assumption denotes the situation where the altruistic motive dominates the nature of remittances to most developing and least-developed receiving countries. In other words, most of these remittances are used to finance the consumption of food, housing, land, and luxuries (see, for example, Rempel and Lobdell, 1978; Adelman \& Taylor, 1990; Glytsos, 1993). The pessimistic view of the growth effect of workers' remittances departs from the moral hazard 
problem and the Dutch Disease hypothesis. The moral hazard effect indicates where remittances receivers in the home country may reduce their labour participation and efforts and, accordingly, affect undesirably economic growth (Chami, Fullenkamp, \& Jahjah, 2003). Dutch Disease hypothesis points to the possibility of appreciation of the real exchange rate of the recipient country's currency as remittances increase, and therefore harmfully affecting tradable exports and economic growth (see AmuedoDorantes and Pozo, 2004; Lartey, Mandelman, \& Acosta, 2012; Rabbi, Chowdhury, \& Hasan, 2013).

\section{Econometric methodology and data}

Two models will be estimated, equation 1 for determinants of remittances and equation 2 for the impact of remittances on economic growth. The specification of remittances determinates model is given as follows:

$\operatorname{lnREM} t=\beta_{0}+\beta_{1} \operatorname{lnYD}_{t}+\beta_{2} \operatorname{lnYF}_{t}+\beta_{3} \operatorname{lnMST}_{t}+\beta_{4} \mathrm{INF}_{\mathrm{t}}+\varepsilon_{\mathrm{t}}$,

Where REM denotes remittances level, YD represents the home country's income, YF is the host country's income, MST stands for migrant stock abroad, INF is the home country's inflation rates, $\varepsilon$ is disturbance term, and $\mathrm{ln}$ is the natural logarithm. The nexus between remittances and economic growth is modelled as follows:

$$
\mathrm{YG}_{\mathrm{t}}=\alpha_{0}+\alpha_{1} \mathrm{CAP}_{\mathrm{t}}+\alpha_{2} \mathrm{REM}_{\mathrm{t}}+\alpha_{3} \mathrm{ODA}_{\mathrm{t}}+\alpha_{4} \mathrm{FD}_{\mathrm{t}}+\alpha_{5} \mathrm{OP}_{\mathrm{t}}+\mathrm{u}_{\mathrm{t}},
$$

Where YG represents real GDP growth, CAP stands for capital formation as a percentage of GDP, REM1 denotes personal remittances inflows to GDP, ODA is official development assistance expressed as a percentage of GDP, FD denotes financial development, OP refers to openness degree, and $\mathrm{u}$ is the error term. As already mentioned in the literature review, the expected sign of REM1 could be either positive or negative. In contrast, the prior expectations of economic theory regarding the effects of CAP, ODA, FD, and OP on economic growth are positive., the prior expectations of economic theory to the effects of CAP, ODA, FD, and $\mathrm{OP}$ on economic growth are positive.

The application of the ARDL bounds testing approach to cointegration and ECM in estimating the long-run relationships and short-run dynamics of equation 1 is conducted in stages, and the same stages will be repeated to estimate the impact of remittances on economic growth 
according to equation 2. Therefore, stages of implementing ARDL bounds testing and ECM will be introduced only for equation 1. In the first stage, the existence of long-run co-integration between workers' remittances and their determinants is tested by estimating a conditional ARDL representation of equation 1 as follows:

$$
\begin{aligned}
& \Delta \ln R E M_{t}=\infty_{0}+\sum_{i=1}^{n} \infty_{1} \Delta \ln R E M_{t-i}+\sum_{i=0}^{n} \infty_{2} \Delta \ln Y D_{t-i}+\sum_{i=0}^{n} \infty_{3} \Delta \ln Y F_{t-i}+ \\
& \sum_{i=0}^{n} \infty_{4} \Delta \ln M S T_{t-i}+\sum_{i=0}^{n} \infty_{5} \Delta I N F_{t-i}+\infty_{6} \ln R E M_{t-1}+\infty_{7} \ln Y D_{t-1}+\infty_{8} \ln Y F_{t-1}+ \\
& \infty_{9} \ln M S T_{t-1}+\infty_{10} I N F_{t-1}+ \\
& e_{t}
\end{aligned}
$$

Where $\Delta$ represents the first difference operator, and $\mathrm{n}$ refers to the maximum lag length. $\infty_{1}, \infty_{2}, \infty_{3}, \infty_{4}$, and $\infty_{5}$, symbolize the short-run coefficients whereas, $\infty_{6}, \infty_{7}, \infty_{8}, \infty_{9}$, and $\infty_{10}$ are the coefficients of the long run. A significance test of no co-integration between REM, YD, YF, MST, and INF is applied with the null hypothesis $\left(\mathrm{H}_{0}: \infty_{6}=\infty_{7}=\infty_{8}=\right.$ $\left.\infty_{9}=\infty_{10}=0\right)$ as against the alternative hypothesis $\left(\mathrm{H}_{1}: \infty_{6} \neq \infty_{7} \neq\right.$ $\infty_{8} \neq \infty_{9} \neq \infty_{10} \neq 0$ ). The Wald test (F statistics) constitutes the core of the bounds test procedure. With two bounds of critical values, if the computed F statistic, at a certain level of significance, is bigger than the upper critical bound value, the null hypothesis of no co-integration is rejected. However, the null hypothesis of no co-integration is accepted if the computed $\mathrm{F}$ statistics is smaller than the lower critical bound value. The result is regarded as inconclusive if the computed $\mathrm{F}$ statistics fall between the upper and lower bound values. Once a long-run relationship is proved, the parameters of the long-run can be estimated employing the following model:

$\operatorname{lnREM}_{\mathrm{t}}=\mathrm{b}_{0}+\mathrm{b}_{1} \operatorname{lnREM}_{\mathrm{t}-1}+\mathrm{b}_{2} \operatorname{lnYD}_{\mathrm{t}-1}+\mathrm{b}_{3} \operatorname{lnYF_{\mathrm {t}-1}}+\mathrm{b}_{4} \ln _{\mathrm{MST}_{\mathrm{t}-1}}+$ $\mathrm{b}_{5} \mathrm{INF}_{\mathrm{t}-1}$

The second step is to estimate the short-run dynamics via the error correction representation of the long-run model. The error correction model is formulated as follows:

$\Delta \operatorname{LnnEM}_{\mathrm{t}}=\delta_{0}+\sum_{\mathrm{i}=1}^{\mathrm{n}} \delta_{1} \Delta \ln \mathrm{REM}_{\mathrm{t}-\mathrm{i}}+\sum_{\mathrm{i}=0}^{\mathrm{n}} \delta_{2} \Delta \mathrm{Ln} \mathrm{YD}_{\mathrm{t}-\mathrm{i}}+\sum_{\mathrm{i}=0}^{\mathrm{n}} \delta_{3} \Delta \mathrm{Ln} \mathrm{YF}_{\mathrm{t}-\mathrm{i}}+$ $\sum_{\mathrm{i}=0}^{\mathrm{n}} \delta_{4} \Delta \mathrm{Ln} \mathrm{MST}_{\mathrm{t}-\mathrm{i}}+\sum_{\mathrm{i}=0}^{\mathrm{n}} \delta_{5} \Delta \mathrm{LnINF}_{\mathrm{t}-\mathrm{i}}+\mu \mathrm{ECM}_{\mathrm{t}-1}+$ $\varepsilon_{\mathrm{t}}$,

Where $\mu$ represents the adjustment speed coefficient and ECM is the error correction term obtained from equation 4 (estimation residuals).

The third stage is to verify the goodness of the selected ARDL 
model by conducting diagnostic tests to ensure that the model is free of the key problems of regression analysis. As well, the structural stability of parameters of the remittance's determinants model will be tested using the CUSUM (cumulated sum of recursive residuals) and CUSUMSQ (cumulated sum of squares of recursive residuals) suggested by Brown, Durbin, and Evans (1975).

The data used are time series for the period 1990-2014. The variables used in this study are defined as follows: REM is real personal remittances in \$US million $(2010=100)$. YD is the real GDP of Yemen in \$US million $(2010=100)$ as a proxy for the home country's income. YF is the real GDP of Saudi Arabia in \$US million (2010=100), as a proxy to the host countries' income ${ }^{1}$. MST is the migrant stock of Yemeni workers abroad proxied by the unemployment rates in Yemen due to the unavailability of migrant stock data. INF is the domestic inflation rate based on the GDP deflator $(2010=100)$. YG is the real GDP growth rate $(2010=100)$. CAP is capital formation to GDP, and REM1 is personal remittances inflows to GDP. ODA is official development assistance to gross national income (GNI). FD is the financial development calculated as the ratio of banks' credit to the private sector to GDP. OP is the openness degree calculated as the ratio of the total value of exports and imports of goods and services to GDP. While data for CAP, REM1 and OP are taken from United Nations Conference for Trade and Development (UNCTAD) Statistics online, the data for other variables were collected from World Development Indicators Data Bank. Eviews 9 software is used in various stages of econometric analysis.

Where $\mu$ represents the adjustment speed coefficient and ECM is the error correction term obtained from equation 4 (estimation residuals).

The third stage is to verify the goodness of the selected ARDL model by conducting diagnostic tests to ensure that the model is free of the key problems of regression analysis. As well, the structural stability of parameters of the remittance's determinants model will be tested using the CUSUM (cumulated sum of recursive residuals) and CUSUMSQ (cumulated sum of squares of recursive residuals) suggested by Brown, Durbin, and Evans (1975).

\footnotetext{
${ }^{1}$ Saudi Arabia is considered as a representative host country as it constitutes the biggest employer of Yemeni expatriate laborers. Saudi Arabia, employed $79 \%$ and $62 \%$ of total Yemeni workers abroad in 2010 and 2013 respectively (World bank, 2020b).
} 
Alhannom, E. A., \& Mushabeb, G. S.

\section{Empirical analysis}

\subsection{Workers' remittances determinants}

To start the bounds test, the univariate properties of the variables' time series must be tested to find their degree of integration and make sure they are not I(2). To do so, both Augmented Dickey-Fuller (ADF) (Dicky \& Fuller, 1981) and Phillips-Perron (PP) (Phillips \& Perron, 1988) tests of the unit root are conducted.

Table 1. Unit Root tests for stationarity for remittances determinants model

\begin{tabular}{|c|c|c|c|c|c|c|}
\hline Variable & ADF test & & & PP test & & \\
\hline & Intercept & Intercept \& trend & Non & Intercept & Intercept \& trend & Non \\
\hline $\operatorname{lnREM}$ & -0.26 & -1.74 & 3.95 & -0.28 & -1.92 & 3.79 \\
\hline dlnREM & $-5.00 *$ & $-4.87 *$ & -1.49 & $-4.99 *$ & $-4.86^{*}$ & $-3.09 *$ \\
\hline $\ln Y D$ & -2.6 & -0.89 & 4.39 & $-5.11^{*}$ & -0.29 & $-4.39 *$ \\
\hline dlnYD & -1.38 & $-6.19 *$ & -1.38 & $-4.82 *$ & $-12.25^{*}$ & $-3.70^{*}$ \\
\hline $\ln Y F$ & 0.09 & -1.41 & 3.73 & 0.11 & -1.41 & 3.81 \\
\hline $\mathrm{d} \ln Y \mathrm{~F}$ & $-5.09 *$ & $-5.47 *$ & $-3.89 *$ & $-5.09 *$ & $-8.17 *$ & -3.89 \\
\hline $\operatorname{lnMST}$ & 1.02 & -0.14 & 1.65 & 0.47 & -0.73 & 2.46 \\
\hline dlnMST & $-2.90 * * *$ & -3.11 & $-2.30 * *$ & $-2.95 * * *$ & -3.10 & $-2.30 * *$ \\
\hline INF & $-3.77 *$ & $-4.72 *$ & -1.32 & $-4.08 *$ & $-8.24 *$ & $-2.10 * *$ \\
\hline dINF & $-4.56^{*}$ & $-4.59 *$ & $-4.68^{*}$ & $-12.50 *$ & $-12.19 *$ & $-13.70^{*}$ \\
\hline
\end{tabular}

$*, * *, * * *$ indicate $1 \%, 5 \%$, and $10 \%$ significance level, respectively.

Source: Prepared by the authors based on EVIEWS 9 output

Table 1 displays that, except for the INF variable, which is $\mathrm{I}(0)$, all other variables of the remittances determinants model are not $\mathrm{I}(0)$ and are I(1). These results enable us to implement the bounds test and ECM to the remittances determinants model.

Table 2. Bounds tests for remittances determinants model

\begin{tabular}{lll}
\hline Computed F statistic & 16.3 & \\
\hline Criticalbound values at 5\% & Lower $=2.850$ & upper $=4.049$ \\
Criticalbound values at $1 \%$ & Lower $=3.817$ & upper $=5.122$ \\
K (number of regressors) & 4 & \\
\hline
\end{tabular}

Critical values are from Pesaran et al. (2001), p.300.

Source: Prepared by the authors based on EVIEWS 9 output 
Concerning the bounds test of co-integration, the computed $\mathrm{F}$ statistic shown in Table 2 is 16.3, which is higher than the upper bound critical values at both the $5 \%$ and $1 \%$ significance levels. As a result, a longrun relationship between REM and its determinants YD, YF, MST, and INF is evidenced, and the long-run elasticities of equation 4 can be estimated.

The long-run model of the remittance's determinants ARDL $(1,2,0,2,2)$ in Table 3 was selected automatically according to AIC with two as a maximum lag due to the small size of the available sample. Elasticities and coefficients of the long-run reveal that except for the elasticity of YD, which is positive and insignificant, all other elasticities and the coefficient of INF are positive and significant. A one per cent increase in host countries' income YF, migrant stock MST, and domestic inflation rates INF causes inward remittances to Yemen to rise by $1.62 \%, 3.9 \%$, and $0.02 \%$, respectively, in the long run. The positive but insignificant effect of YD is in line with the results of Lianos (1997) and Agarwal and Horowitz (2002). The strong influence of YF refers to the critical role played by host countries' income in explaining variations in workers' remittances in Yemen, which is consistent with the conclusions ofElbadawi and Rocha (1992), Silva and Huang (2006), Aydas et al. (2005), Adenutsi (2014), McCracken et al. (2017). The strongest influence on workers' remittances comes from MST at a $1 \%$ significance level, which goes in line with the findings of Lianos (1997), Lueth and Ruiz-Arranz (2006), Freund and Spatafora (2008), Singh et al. (2011), Bettin et al. (2014), and Moussir and Tabit (2016). Table 3 shows that a positive, albeit weak, effect comes from domestic inflation on the remittances level and thus adds evidence to those of Lianos (1997), Elsakka and Mcnabb(1999), Lueth and Ruiz-Arranz (2007), Begum and Sutradhar (2012), Adenutsi (2014), and Prasad and Trivedi (2015).

The ECM results of the short-run elasticities, to a large extent, confirm those of the long-run, except that of MST, whose impact appears insignificant. ECMt-1 is significant at a $1 \%$ level and has the appropriate (negative) sign approving the already concluded long-run relationship between real workers' remittances level and its determinants in Yemen. The value of the ECMt-1 coefficient $(-0.41)$ denotes a moderate speed of adjustment ( $41 \%$ a year) of the level of remittances to changes in the independent variables before approaching its equilibrium value. 
Alhannom, E. A., \& Mushabeb, G. S.
Workers' Remittances in Yemen: Macroeconomic

Determinants and Impact on Economic Growth

Table 3. Long and short-run coefficients of remittances determinants model

\begin{tabular}{lccc}
\hline \multicolumn{2}{c}{ Long-run coefficients of ARDL $(1,2,0,2,2)$} & Model (dependent variable lnREM) \\
\hline $\begin{array}{l}\text { Independent } \\
\text { Variables }\end{array}$ & Coefficient & Prob \\
lnYD & 0.91 & t-statistic & 0.1250 \\
lnYF & 1.62 & 1.67 & 0.0347 \\
lnMST & 3.92 & 2.44 & 0.0002 \\
INF & 0.02 & 5.65 & 0.0132 \\
INPT & -53.32 & 3.00 & 0.0000 \\
\hline & ECM representation of ARDL $(1,2,0,2,2)($ dependent variable dlnREM) \\
\hline dlnYD & -0.11 & -0.19 & 0.8502 \\
dlnYD(-1) & -3.24 & -6.35 & 0.0001 \\
dlnYF & 0.66 & 2.70 & 0.0222 \\
dlnMST & 2.80 & 1.77 & 0.1064 \\
dLMST(-1) & -4.04 & -2.26 & 0.0471 \\
dINF & 0.01 & 4.23 & 0.0017 \\
dINF(-1) & -0.00 & -2.14 & 0.0576 \\
ECMt-1 & -0.41 & -4.53 & 0.0011 \\
\hline
\end{tabular}

R. squared (0.998) S.E of Regression (0.067) F. statistic 474(0.000))

\begin{tabular}{ll}
\hline & Autocorrelation (Breusch-Godfrey Serial Correlation LM Test) \\
& $\mathrm{F}=0.67[0.53]$ Chi-Square $=3.16[0.21]$ \\
Functional form misspecification (Ramsey RESET) \\
Tests & $\mathrm{F}=1.58[0.24]$ \\
& Non -Normality (Jarque-Bera Test) $2.35[0.31]$ \\
& Heteroskedasticity (Breusch-Pagan-Godfrey test) \\
& $\mathrm{F}=1.40[0.30]$ Chi-Square $=13.3[0.27]$ \\
\hline
\end{tabular}

Source: Prepared by the authors based on EVIEWS 9 output

The last stage of the analysis of the remittance's determinants model is to ensure the goodness and stability of the basic model that gives us the long and short runs relationships. The statistical information at the end of Table 3 shows that our model is strong and free of major regression problems. The tests of the stability of the model's parameters are presented in Figures 2 and 3. The graphical presentations of both CUSUM and CUSUMSQ tests disclose that our model is stable and correctly specified. 


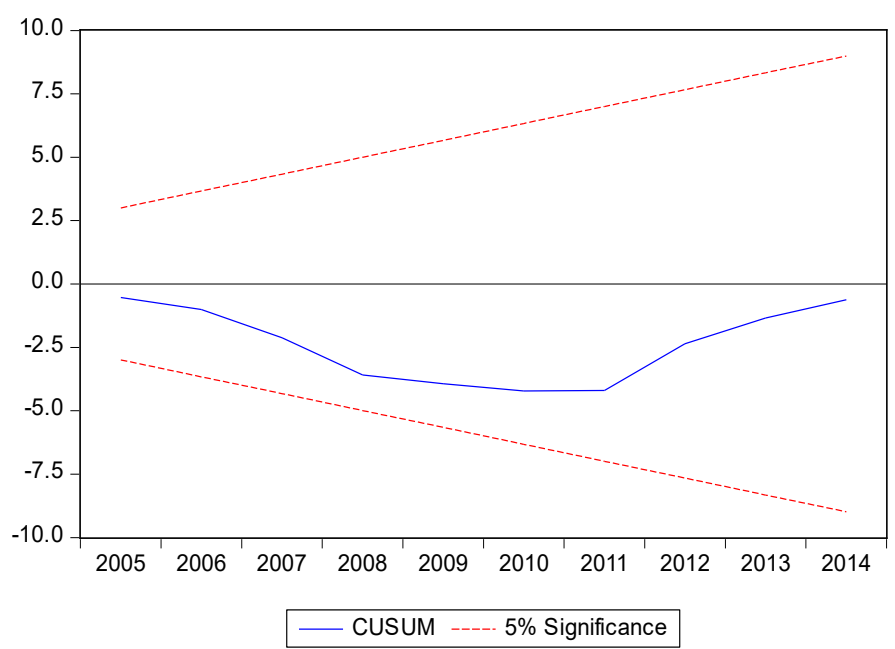

Figure 2. Plot of CUSUM

Source: Authors' work based on EVIEWS 9 output

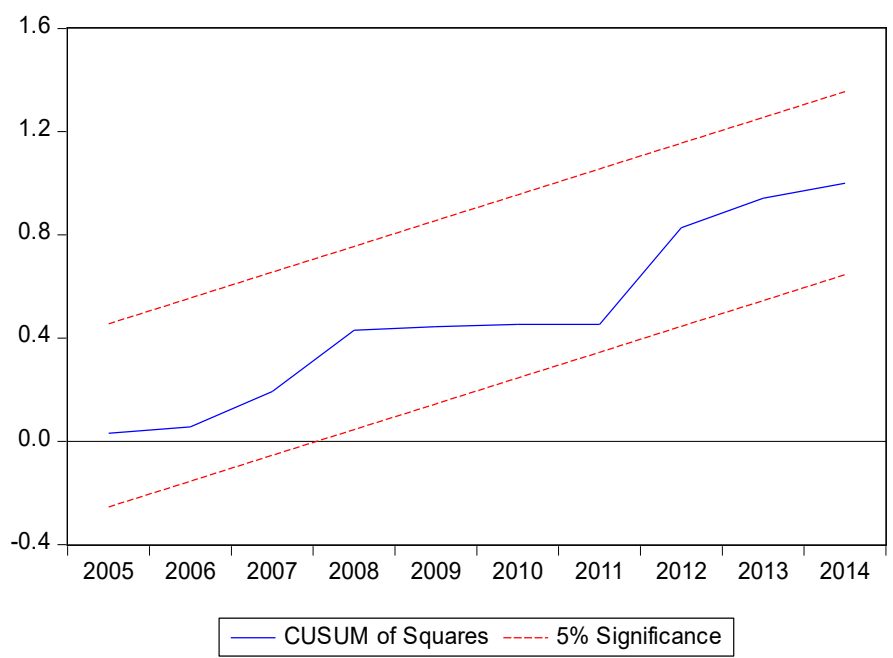

Figure 3. Plot of CUSUMSQ

Source: Authors' work based on EVIEWS 9 output

\subsection{Impact of remittances on economic growth}

To start with the economic growth model, ADF and PP stationarity tests were conducted. Table 4 shows that, except for the FD variable, which is not $\mathrm{I}(0)$ and $\mathrm{I}(1)$, all other variables of the economic growth model are stationary in level. As a result, the bounds test can be conducted. 
Alhannom, E. A., \& Mushabeb, G. S.
Workers' Remittances in Yemen: Macroeconomic

Determinants and Impact on Economic Growth

Table 4. Unit root tests for stationarity for economic growth model

\begin{tabular}{|c|c|c|c|c|c|c|}
\hline Variable & ADF Test & & & PP test & & \\
\hline & Intercept & Intercept \& trend & Non & Intercept & Intercept \& trend & Non \\
\hline YG & $-4.82 *$ & $-6.30^{*}$ & -1.43 & $-4.82 *$ & $-13.92 *$ & $-2.96^{*}$ \\
\hline dYG & $-4.99 *$ & $-4.66^{*}$ & $-4.60 *$ & $-19.90 *$ & $-18.80 *$ & $-16.30^{*}$ \\
\hline CAP & $-3.48 * *$ & -3.22 & -0.09 & $-4.49 *$ & $-3.90 * *$ & 0.34 \\
\hline dCAP & $-3.13^{* *}$ & $-3.39 * * *$ & $-3.3^{*}$ & $-6.47 *$ & $-7.60^{*}$ & $-6.65^{*}$ \\
\hline REM1 & $-4.79 *$ & $-3.55 * * *$ & $-4.03 *$ & $-4.66^{*}$ & $-3.44 * * *$ & $-3.99 *$ \\
\hline dREM1 & $-7.75^{*}$ & $-8.76^{*}$ & $-7.75^{*}$ & $-7.84 *$ & $-10.23 *$ & $-7.40^{*}$ \\
\hline ODA & $-2.70 * * *$ & -2.79 & $-2 * *$ & $-2.70 * * *$ & -2.95 & $-2 * *$ \\
\hline dODA & $-5.88 *$ & $-5.76^{*}$ & $-5.98 *$ & $-5.88 *$ & $-5.76^{*}$ & $-6.17 *$ \\
\hline FD & -1.49 & -1.71 & -0.22 & -1.49 & -1.83 & -0.22 \\
\hline $\mathrm{dFD}$ & $-4.45^{*}$ & -3.22 & $-4.45^{*}$ & $-4.33 *$ & $-4.21 * *$ & $-4.45^{*}$ \\
\hline $\mathrm{OP}$ & $-3.46^{* *}$ & $-3.70 * *$ & -1.40 & $-3.40 * *$ & $-3.54 * * *$ & -1.34 \\
\hline $\mathrm{dOP}$ & $-5.52 *$ & $-5.64 *$ & $-5.34 *$ & $-10^{*}$ & $-12.26^{*}$ & $-8.38 *$ \\
\hline
\end{tabular}

$*, * *, * * *$ indicate $1 \%, 5 \%$, and $10 \%$ significance level, respectively.

Source: Prepared by the authors based on EVIEWS 9 output.

Table 5 shows that $\mathrm{F}$ statistics is 5.26 and higher than the upper bound values at both $5 \%$ and $1 \%$ levels of significance. As a result, the long-run relationships between economic growth and its determinants, including workers' remittances, have been proven.

Table 5. Bounds tests for economic growth model

\begin{tabular}{lll}
\hline Computed F statistic & 5.26 & \\
\hline Criticalbound values at $5 \%$ & Lower $=2.649$ & upper $=3.805$ \\
Criticalbound values at $1 \%$ & Lower $=3.516$ & upper $=4.781$ \\
K (number of regressors) & 5 & \\
\hline
\end{tabular}

Critical values are from Pesaran et al. (2001), p. 300.

Source: Prepared by the authors based on EVIEWS 9 output

This bounds test result, extracted from a conditional ARDL model of equation 2, enables us to estimate the associated long-run and ECM representations of the model as it has done with the remittances determinants model. Table 6 shows that ARDL $(2,1,2,2,2,2)$ model was selected based on AIC with two as a maximum lag was chosen. The longrun coefficients of economic growth determinants, shown in Table 6, appear 
positive and significant at a $1 \%$ significance level. The coefficient of REM 1 is 0.43 , which points to a moderate impact compared to those of ODA and FD. This may indicate that inward remittances in Yemen are largely directed to the consumption of necessities and real estate, and a small part is allocated to investment purposes. A stronger association was observed between ODA and economic growth, which might be traced back to the domination of investment spending in allocating the financial resources of ODA. Table 6 also displays that FD has the strongest influence on economic growth, which may be attributed to the fact that the period of 1990-2014 witnessed an increase in the number of banks and diversification of their activities, and the financial system has undergone a reform program.

In contrast, Table 6 shows that the openness degree effect is weak, which can be interpreted by the weak structure of foreign trade in Yemen. On the one hand, the demand for imports increases rapidly owing to the weak productive base and necessities; on the other dominates the high growth rate of the population and imports. Moreover, crude oil constitutes about $90 \%$ of exports, which may weaken the effect of exports on economic growth.

The results of the ECM representation of the selected model ARDL $(2,1,2,2,2,2)$ refer to a greater positive impact of REM1 on economic growth in the short run and a negative and significant effect for lagged REM1. The influence of capital formation CAP in the short run is very close to that of the long run. Whilst ODA impact in the short run turned out to be negative and insignificant, FD plays a positive and strong effect close to the long run. Openness degree seems to have a trivial, insignificant association with economic growth in the short run. $\mathrm{ECM}_{\mathrm{t}-1}$ is statically significant at a $1 \%$ level and has a negative sign. This confirms the already-reached conclusion that a long-run relationship exists between economic growth and its determinants, including workers' remittances. Besides, the value of the $\mathrm{ECM}_{\mathrm{t}-1}$ coefficient (-3.45) is high, indicating a high speed of adjustment ( $345 \%$ a year) of economic growth to variations in the independent variables before approaching its equilibrium value.

It is evident from Table 5 that our model is good and free of key regression problems. Moreover, figures 4 and 5 of the CUSUM and CUSUMSQ tests demonstrate this. 
Alhannom, E. A., \& Workers' Remittances in Yemen: Macroeconomic Mushabeb, G. S. Determinants and Impact on Economic Growth

Table 6. Long and short-run coefficients of economic growth model

\begin{tabular}{|c|c|c|c|}
\hline \multicolumn{4}{|c|}{ Long-run coefficients of ARDL $(2,1,2,2,2,2)$ Model (dependent variable YG) } \\
\hline Independent Variables & Coefficient & t-statistic & Prob \\
\hline CAP & 0.52 & 5.21 & 0.0070 \\
\hline REM1 & 0.43 & 8.37 & 0.0010 \\
\hline ODA & 1.31 & 9.97 & 0.0006 \\
\hline FD & 2.48 & 11.44 & 0.0003 \\
\hline $\mathrm{OP}$ & 0.39 & 6.38 & 0.0030 \\
\hline INPT & -41.36 & -8.70 & 0.0010 \\
\hline \multicolumn{4}{|c|}{ ECM representation of ARDL $(2,1,2,2,2,2)$ (dependent variable dYG) } \\
\hline dYG(-1) & 1.51 & 10.91 & 0.0004 \\
\hline dCAP & 0.55 & 2.66 & 0.0566 \\
\hline dREM1 & 2.10 & 4.98 & 0.0076 \\
\hline dREM1(-1) & -1.22 & -3.98 & 0.0164 \\
\hline dODA & -1.49 & -1.91 & 0.1293 \\
\hline dODA(-1) & -1.96 & -4.29 & 0.0127 \\
\hline $\mathrm{dFD}$ & 2.20 & 5.79 & 0.0044 \\
\hline $\mathrm{dFD}(-1)$ & -3.99 & -4.91 & 0.0080 \\
\hline $\mathrm{dOP}$ & 0.12 & 0.92 & 0.4087 \\
\hline $\mathrm{dOP}(-1)$ & -0.98 & -6.38 & 0.0031 \\
\hline $\mathrm{ECM}_{\mathrm{t}-1}$ & -3.45 & -15.74 & 0.0001 \\
\hline \multicolumn{4}{|c|}{ R. squared (0.989) S.E of regression (0.91) F. statistic 23.88 (0.003)) } \\
\hline $\begin{array}{l}\text { Diagnostic } \\
\text { Tests }\end{array}$ & $\begin{array}{l}\text { Autocorrela } \\
\text { LM Test) } F \\
\text { Functional } f \\
\text { Normality } \\
\text { Heterosceda } \\
F=0.59\end{array}$ & $\begin{array}{l}\text { Hodfrey seri } \\
\text { ESET) } \mathrm{F}= \\
0.314[0.8 \\
\text {-Pagan-Go } \\
=14.8[0.5\end{array}$ & \\
\hline
\end{tabular}

Source: Prepared by the authors based on EVIEWS 9 output 
\begin{tabular}{l|l|l} 
Management \& Economics Research Journal & Vol. 3 No. 2 (2021) & pp. 41-62
\end{tabular}

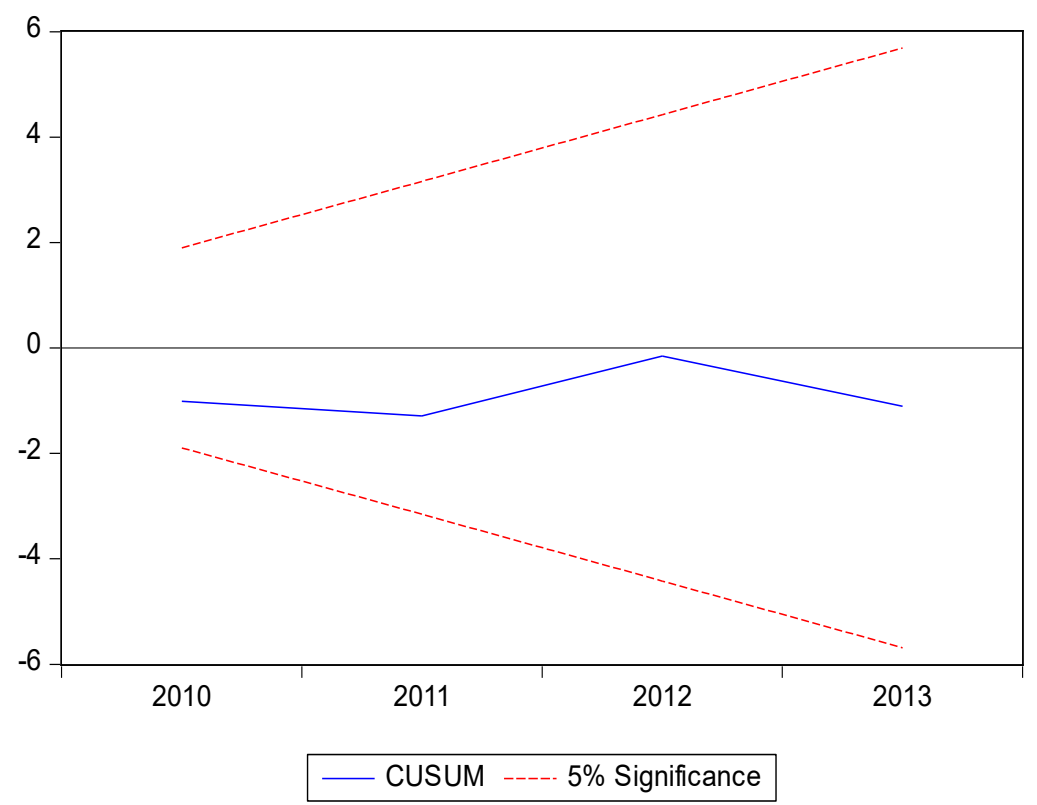

Figure 4. Plot of CUSUM

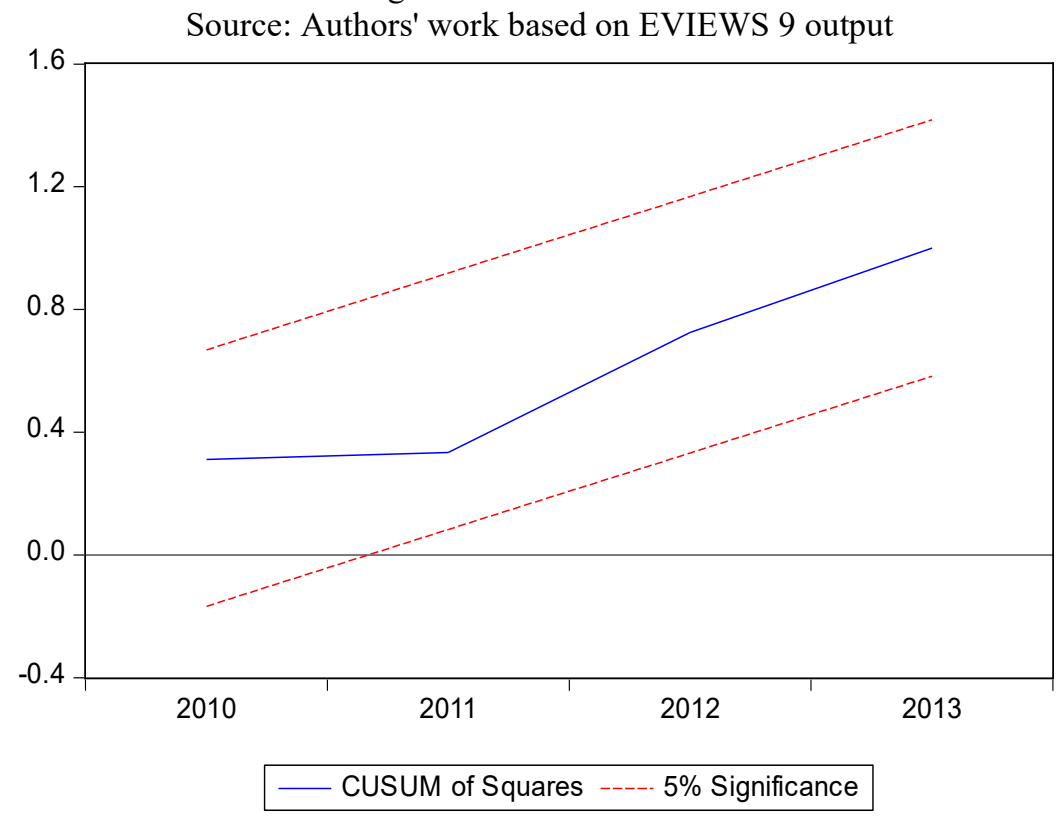

Figure 5. Plot of CUSUMSQ

Source: Authors' work based on EVIEWS 9 output 
Alhannom, E. A., \& Mushabeb, G. S.

\section{Conclusions and policy implications}

This study was motivated by the need to explore the macroeconomic aspects of workers' remittances flows to Yemen, especially their determinants and impact on economic growth. ARDL bounds test to cointegration and ECM were applied to data covering 1990 to 2014. The macroeconomic conditions of the home and host countries influence worker remittances in Yemen. It is found that there is a long-run relationship between workers' remittances and their determinants (YD, YF, MST, and INF). Migrant stock abroad and income level in the host countries were found to be positively, strongly and significantly correlated with remittances level, with a feeble impact on domestic inflation rates. The significant impact of the host countries' income reaffirms the volatile nature of workers' remittances as a source of development finance. We did not find the home country's income significant in explaining the behaviour of remittances level. The short-run dynamics' results support these influences of the long run, except that of MST, which is observed to be insignificant. The policy implication of these results is that raising the remittances level of Yemeni expatriates depends essentially on increasing the stock of migrants abroad, which, on the one hand, is faced with constraints and has negative economic and social effects on the other. Furthermore, a lesser weight should be given to remittances in the strategic planning process, considering the increasing potential of the conditions in the neighbouring host countries to be changed.

Concerning the impact of remittances on economic growth, a longrun relationship between economic growth on the one hand and remittances and other determinants (CAP, ODA, FD, OP) on the other was demonstrated. At a 1\% level of significance, it was shown that both the control variables and worker remittances REM1 were positively correlated with economic growth. However, the impact of remittances appears to be moderate (0.43), with stronger influences observed for FD and ODA (2.43 and 1.31 , respectively). In the short run, the workers' remittances impact was found to be strong, while that of FD was negative and insignificant. The policy implication of these findings is that using remittances as a means of economic growth can be enhanced by encouraging migrants to direct a larger portion of their savings to productive investment activities. In addition, as financial development proved to be a strong factor impacting economic growth, encouraging migrants to transfer and channel their remittances through banks would greatly benefit Yemen's economy. 


\section{Declaration of conflicting interests}

The author(s) declared no potential conflicts of interest with respect to the research, authorship, and/or publication of this article.

\section{References}

Adelman, Irma, \& Taylor, J. E. (1990). Is Structural Adjustment with a Human Face Possible? The Case of Mexico. Journal of Development Studies, 26, 387407.https://doi.org/10.1080/00220389008422161

Adenutsi, Deodat E. (2014). Macroeconomic Determinants of Workers' Remittances and Compensation of Employees in Sub-Saharan Africa. The Journal of Developing Areas, 48(1), 337-360.https://doi.org/10.1353/jda.2014.0015

Agarwal, R., \& Horowitz, A. W. (2002). Are international remittances altruism or insurance? Evidence from Guyana using multiple-migrant households. World Development, 30, 2033-2044.https://doi.org/10.1016/s0305-750x(02)00118-3

Amuedo-Dorantes, C., \& Pozo, S. (2004). Worker's Remittances and the Real Exchange Rate: A Paradox of Gifts. World Development, 32, 14071417.https://doi.org/10.1016/j.worlddev.2004.02.004

Ayda, O.T., Neyapti, B., Metin-Ozcan, K. (2005). Determinants of Workers Remittances: The Case of Turkey. Emerging Markets Finance and Trade, 41(3), 5369.https://doi.org/10.1080/1540496x.2005.11052609

Bettin, G., Presbitero, A. F., \& Spatafora, N.(2014). Remittances and Vulnerability in Developing Countries (IMF Working Paper NO. WP/14/13).https://doi.org/10.5089/9781484385081.001

Barajas, A., Chami, R., Fullenkamp, C., Gapen, M., and Montiel, P. (2009). Do Workers' Remittances Promote Economic Growth? (IMF Working Paper NO. WP/153/09).

Begum, M. N., \& Sutradhar, R. R. (2012). Behaviour of remittance inflows and its determinants in Bangladesh (Bangladesh Bank Working Paper No. 1202).

Brown, R.L., Durbin, J., \& Evans J. M. (1975). Techniques for testing the constancy of regression relations over time. Journal of Royal Statistical Society, Series B,37(2), 149-163.https://doi.org/10.1111/j.2517-6161.1975.tb01532.x

Chami, R., Fullenkamp, C., \& Jahjah, S. (2003). Are Immigrant Remittances Flows a Source of Capital for Development? (IMF Working Paper NO.WP 189/03).https://doi.org/10.5089/9781451859638.001

Chami, R., Hakura, D., \& Montiel, P. (2009). Remittances: An Automatic Output Stabilizer? (IMF Working Paper NO WP 91/09).https://doi.org/10.5089/9781451872385.001

Daway-Duacanes, Sarah Lynne. (2015). A note on the effects of remittances and overseas migration on some Philippine statistics. Philippine Review of Economics, 51(1), $95-116$.

Dickey, D., \& Fuller, W. (1981). Likelihood Ratio Statistics For Autoregressive Time Series With A Unit Root. Econometrica, 49(S), 105772.https://doi.org/10.2307/1912517 
Alhannom, E. A., \& Mushabeb, G. S.
Workers' Remittances in Yemen: Macroeconomic

Determinants and Impact on Economic Growth

Edwards C.A., \& Ureta, M. (2003). International Migration, Remittances and Schooling: Evidence from El Salvador. Journal of Development Economics, 72(2), 429461.https://doi.org/10.1016/s0304-3878(03)00115-9

Elbadawi, I. A., \& Rocha, R. (1992). Determinants of Expatriate Workers' Remittances in North Africa and Europe (World Bank Working Paper Series NO. 1038).

El-Sakka, M., \& MaNabb, R. (1999). The Macroeconomic Determinants of Migrant Remittances. World Development, 27, 1493-1502.https://doi.org/10.1016/s0305750x(99)00067-4

ESCWA, (2014). Directing remittances of Yemeni workers abroad and migrants towards development.

https://www.unescwa.org/sites/www.unescwa.org/files/page_attachments/y11.pdf, 10/10/2020.

Ezeoha, A.E. (2013). Financial determinants of international remittance flows to the SubSaharan African region. International Migration, 51(s1), e84e97.https://doi.org/10.1111/imig.12061

Fajnzylber, P., \& Lopez, J. H. (2007), Close to Home: The Development Impact of Remittances in Latin America, mimeo (Washington: World Bank).

Freund, C., \& Spatafora, N. (2008). Remittances, Transaction Costs, Determinants and Informality. Journal of Development Economics, 86(2), 356366.https://doi.org/10.1016/j.jdeveco.2007.09.002

Giuliano, P., \& Ruiz-Arranz, M. (2009). Remittances, financial development, and growth. Journal of Development Economics, 90, 144152.https://doi.org/10.1016/j.jdeveco.2008.10.005

Glytsos, N. (1988). Remittances in Temporary Migration: A Theoretical Model and Its Testing with the Greek-German Experience. Review of World Economics, 124, 524-549.https://doi.org/10.1007/bf02708664

Glytsos, N. (1993). Measuring the income effects of migrant remittances: A methodological approach applied to Greece. Economic Development and Cultural Change, 42, 131-168.https://doi.org/10.1086/452068

Glytsos, N.P. (2002). A Model of Remittances Determination Applied to Middle East and North Africa Countries. Centre of Planning and Economic Research 73. https://econwpa.ub.uni-muenchen.de/econ-wp/lab/papers/0505/0505016.doc.gz

Gupta, P. (2005). Macroeconomic Determinants of Remittances: Evidence from India (IMF Working Paper No. WP 224/05).https://doi.org/10.5089/9781451862430.001

Higgins, M., Hysenbegasi, A., \& Pozo, S. (2004). Exchange-rate uncertainty and workers' remittances. Applied Financial Economics, 14(6), 403411.https://doi.org/10.1080/09603100410001673630

Hor, C., Pheang, P. (2017). Analysis Determinant Factors Effect on Migrant Workers' Remittances Flow to the CLMV Countries. International Journal of Economics and Financial Issues, 7(2), 202-207.

Katseli, L., \& Glytsos, N. (1986). Theoretical and Empirical Determinants of International LabourMobility: A Greek-German Perspective (Centre for Economic Policy Research Working Paper NO. 148).

Kroft, Kory, \& Huw, Lloyd-Ellis., (2002). Further Cross-Country Evidence on the Link 
Between Growth, Volatility and Business Cycles. Manuscript for preparation. http://qed.econ.queensu.ca/pub/faculty/lloyd-ellis/papers/kory.pdf.

Lartey, E. K., Mandelman, F. S., \& Acosta P. A. (2012). Remittances, Exchange RateRegimes and the Dutch Disease: A Panel Data Analysis. Review of International Economics, 20(2), 377-395.https://doi.org/10.1111/j.14679396.2012.01028.x

Lianos, T.P. (1997). Factors Determining Migrant Remittances: The Case of Greece. International Migration Review,31(1), 7287.https://doi.org/10.1177/019791839703100104

Lucas, R., \& Stark, O. (1985). Motivations to Remit: Evidence from Botswana. The Journal of Political Economy, 93, 901-918.https://doi.org/10.1086/261341

Lucas, R. E. B. (2005). International Migration and Economic Development. http://www.eelgar.com/shop/isbn/9781845423834.

Lueth, E., \& Ruiz-Arranz, M. (2006). A Gravity Model of Workers' Remittances (IMF Working Paper NO. WP/290/06). https://doi.org/10.5089/9781451865509.001

McCracken, S., Carlyn, Ramlogan-Dobson, \& Stack, Marie M. (2017). A gravity model of remittance determinants: evidence from Latin America and the Caribbean. Regional Studies, 51(5), 737-749. https://doi.org/10.1080/00343404.2015.1133904

Mesnard, A. (2001). Temporary migration and intergenerational mobility. Louvain Economic Review, 67(1), 59-88.

Mim, S., \& Ali, Mohamed S. (2012). Through Which Channels Can Remittances Spur Economic Growth in MENA Countries? International Journal of Economic Perspectives, 6(3), 279-294.https://doi.org/10.2139/ssrn.2006818

Narayan, P.K. (2004). Reformulating critical values for the bounds F-statistics approach to co-integration: an application to the tourism demand model for Fiji (Department of Economics Discussion Papers No. 02/04 Monash University).

Panda, P. D., \&Trivedi, P. (2015). Macroeconomic determinants of remittances: A crosscountry analysis. Journal of International Economics, 6(2), 83-100.

Pesaran, M.H., \& Shin, Y. (1996). Co-integration and Speed of Convergence to Equilibrium. Journal of Econometrics, 71(1-2), 117143.https://doi.org/10.1016/0304-4076(94)01697-6

Pesaran, M.H., Shin, Y., \& Smith, R.J. (2001). Bounds testing approaches to the analysis of level relationships. Journal of Applied Econometrics, 16(3), 289326.https://doi.org/10.1002/jae.616

Phillips, P. C., \& Perron, P. (1988). Testing For A Unit Root İn Time Series Regression. Biometrika, 75(2), 335-346.https://doi.org/10.1093/biomet/75.2.335

Rabbi, F., Chowdhury, M. B., \& Hasan, M. (2013). Macroeconomic impact of remittances and the Dutch Disease in a developing country. American Journal of Economics, $3(5 \mathrm{C}), 156-60$.

Ratha, D. (2013). The Impact of Remittances on Economic Growth and Poverty Reduction. Migration Policy Institute, Washington, D.C. https://www.migrationpolicy.org/pubs/Remittances-PovertyReduction.pdf

Rempel, H., \& Lobdell, R. (1978). The role of Urban to Rural Remittances in rural 
Alhannom, E. A., \& Mushabeb, G. S.

Workers' Remittances in Yemen: Macroeconomic

Determinants and Impact on Economic Growth

development. Journal of Development Studies, 14, 324341.https://doi.org/10.1080/00220387808421678

Singh, R., Haacker, M., Lee, K-W., \& Goff, M.L. (2011). Determinants and macroeconomic impact of remittances in Sub-Saharan. Africa Journal of African Economies, 20(2), 312-340. https://doi.org/10.1093/jae/ejq039

Swamy, G. (1981). International Migrant Workers' Remittances: Issues and Prospects (World Bank Staff Working Paper NO. 481).

Tabit, S., Moussir, C.E. (2016). Macroeconomic determinants of migrants' remittances: Evidence from a panel of developing countries. International Journal of Business and Social Research,6(7),1-11. https://doi.org/10.18533/ijbsr.v6i7.969

UNCATAD, (2020). Economic Trends, Trade Indicators, and External Financial Resources. https://unctadstat.unctad.org/wds/ReportFolders/reportFolders.aspx

Vargas - Silva, C., \& Huang, P.(2006). Macroeconomic Determinants of Worker's Remittances: Host Versus Home Country's Economic Conditions. Journal of International Trade \& Economic Development,15(1), 8199.https://doi.org/10.1080/09638190500525779

World Bank, (2020a). World Development Indicators Data bank, https://databank.worldbank.org/source/world-development-indicators\#.

World Bank, (2020b). Migration and Remittances Data, https://www.worldbank.org/en/topic/migrationremittancesdiasporaissues/brief/mig ration-remittances-data

World Bank, (2020c). Remittances to low-and Middle-income Countries, https://blogs.worldbank.org/peoplemove/data-release-remittances-low-and-middleincome-countries-track-reach-551-billion-2019.

Yang, Dean, \& Choi, HwaJung (2007). Are Remittances Insurance? Evidence from Rainfall Shocks in the Philippines. World Bank Economic Review, 21(2), 219248.https://doi.org/10.1093/wber/lhm003

Yoshino, N., Farhad, Taghizadeh-Hesary, \& Miyu, O. (2019). Determinants of International Remittance Inflows in Middle Income Countries in MENA, Asia and Pacific (Asian Development Bank Institute Working Paper Series No. 964).https://doi.org/10.2139/ssrn.3541026 